\title{
IMPACT OF OZONATION PROCESS ON THE CONTENT OF BIOACTIVE COMPOUNDS WITH ANTIOXIDANT PROPERTIES IN SCOTS PINE (PINUS SYLVESTRIS L.) SHOOTS AS WELL AS YIELD AND COMPOSITION OF ESSENTIAL OILS
}

\author{
- Research paper -
}

\author{
Natalia MATŁOK ${ }^{1 *}$, Józef GORZELANY** Tomasz PIECHOWIAK ${ }^{* *}$, Piotr ANTOS ${ }^{* * *}$, Miłosz \\ ZARDZEWIAŁY* ${ }^{*}$, Maciej BALAWEJDER ${ }^{* *}$ \\ * Department of Food and Agriculture Production Engineering, Collegium of Natural Sciences, \\ University of Rzeszow, St. Zelwerowicza 4, 35-601 Rzeszów, Poland \\ ** Department of Chemistry and Food Toxicology, Collegium of Natural Sciences, University of \\ Rzeszow, St. Ćwiklińskiej 1a, 35-601 Rzeszów, Poland \\ ***:Department of Computer Engineering in Management, Rzeszow University of Technology, 35- \\ 959 Rzeszów, Poland;
}

\begin{abstract}
This study examined the impact of the ozonation procedure on the content of bioactive compounds in young shoots of Pinus sylvestris L. as well as on the yield and the composition of the essential oils and volatile fraction. The ozonation process consisted of exposure of the raw material during 5, 15 and 30 min to the ozone gas with the concentration of 10 and $100 \mathrm{ppm}$, and then it was stored for 24 hours. In the ozonated pine shoots, the content of vitamin $\mathrm{C}$ overall content of polyphenol content and antioxidant potential were determined. It was found that the investigated parameters increased as a result of the utilized procedure. The observed increase in the content of tested bioactive compounds was dependent on exposition time and was found to be highest for ozonated material for 15 min with ozone gas at a concentration of $10 \mathrm{ppm}$. As a result of the ozonation procedure the content of polyphenolic compounds and vitamin $\mathrm{C}$ content increased. Whereas it, did not have a significant effect on composition of the obtained essential oils. It was found that ozone is an effective elicitor, which allows increasing the content of bioactive compounds in pine shoots.
\end{abstract}

Keywords: scots pine; ozonation; antioxidant activity; polyphenols; essential oils; HS-SPME;

\section{INTRODUCTION}

Scots Pine (Pinus sylvestris L.) is the most popular and widespread conifer in the world. In Europe, it covers a distance of $14000 \mathrm{~km}$ and stretches from Spain to Russia (Mason et al., 2000). Pinus sylvestris $\mathrm{L}$. is very important species responsible for wood production, especially in the Scandinavian countries. It is also valued for its healing and aromatic properties and as a source of various plant materials, such as buds (Pini Gemmae), young shoots (Pini Turiones) and needles (Pini Folium) (Strzelecka et al., 2003; Bączek et al., 2017). Young pine shoots are a valuable source of compounds with a high nutritional value including antioxidants, polyphenols and vitamin C (Ulukanli et al., 2014). Pinus sylvestris L. like other coniferous species, it is also a valuable source of essential oils (Pini Oleum) (Matłok et al., 2020). The world production

Received: 27.07.2020.

Accepted in revised form: 27.09.2020 of pine essential oils is about $40 \mathrm{t}$, and their main producers are China and Russia. These oils can be found mainly in needles and non-woody, young shoots, and their yield is about $0.87 \%$ of a dry mass (Daugavietis t al., 2002). Pine essential oils contain mainly monoterpenes and sesquiterpenes but also juniperic and sabinic acid derivatives, tannins and vitamin C (Tümenet al., 2010; Thoss et al., 2007; Judžentienè et al. 2008). These compounds, due to their properties, exhibit pharmacological activities, including: expectorant, antispasmodic, antimicrobial, warming, diaphoretic, diuretic and choleretic. Pine oils are also used in the cosmetics and perfumery industries (Motiejûnaitë et al, 2004; Kohlmûnzer, 2010; Kędzia et al., 2012).

The market value of aromatic herbal raw materials, including pine shoots, depends on a number of quality parameters. One of the most important is the microbiological indicator (Tanko et al., 2005; European Spice Association, 2013). There is a number of methods that have been developed to reduce the microbial load of aromatic raw materials,

${ }^{1}$ Corresponding author. E-Mail address: nmatlok@ur.edu.pl 
but it seems that only the use of ozone is the most promising technique because it leaves no residue and is environmentally friendly, compared to other methods (Brodowska et al., 2014a; Torlak et al., 2013; Rice et al., 2017). Neverless, essential oils contained in aromatic raw material may be susceptible to reaction with ozone, as reported by Weschler and Shields (1999). Therefore, it is important to verify the optimal doses of ozone that can cause oxidative stress and, consequently, stimulate the production of antioxidants such as polyphenols and vitamin $\mathrm{C}$ while maintaining the efficiency of essential oils that can be obtained from plant resources (Birben et al., 2012).

There is a literature gap on the ozonation process of pine shoots and its impact on the plant material. Therefore, the aim of the presented research was investigation of the impact of ozonation process of young pine shoots (Pinus sylvestris L.) on the content of bioactive compounds and the efficacy and composition of the essentials oils.

\section{MATERIALS AND METHODS}

\section{Plant materials}

The plant resource used in the experiment comprised young shoots of Scots pine (Pinus sylvestris L.).

The material was as described by Matłok et al. (2020).

\section{The ozone treatment of the plant material}

Samples of pine shoots $(500 \mathrm{~g} \pm 5)$ were placed into the ozonation chamber described by Antos et al. (2018) and Gorzelany et.al. (2016). This device was used in combination with the Ozone Solution TS 30 ozone generator, and the ozone concentration was measured with the 106M UV-Ozone Solution detector, with a measuring range of $0-1000 \mathrm{ppm}$. Pine shoots were exposed to gaseous ozone at the concentration of $10 \mathrm{ppm}$ and $100 \mathrm{ppm}$ for 5,15 and 30 minutes with $4 \mathrm{~m}^{3} \mathrm{~h}^{-1}$ flow rate of ozone. The ozonation process was carried out at constant temperature of $20^{\circ} \mathrm{C}$.

After the ozonation process the pine shoots samples were placed in container and stored at temperature of $25^{\circ} \mathrm{C}$ for 24 hours.

The experiments were performed in triplicate. Next, the material was subjected to further analysis.

Total phenolic content assay, antioxidant activity The total polyphenolic content was determined using the Folin-Ciocalteu reagent method as described by Matłok et al. (2020).

The free radical scavenging activity was determined by ABTS and DPPH according to Matłok et al. (2020).

\section{Ascorbic acid content}

The determination of ascorbic acid content was determined using a procedure described by Matłok et al. (2020).

\section{Head Space-Solid Phase Microextraction HS- SPME}

The control and the ozonated material were subjected to Head Space - Solid Phase Microextraction Analyses that were performed according to the procedure described by Matłok et al. (2019). The composition of the compounds desorbed from SPME fibre was examined using gas chromatograph (GC-MS, Varian 450GC coupled with 240 MS).

\section{Isolation and chromatographic analysis of the essential oils}

Essential oils were isolated from plant material (200 $\mathrm{g} \pm 1$ ) with the use of steam distillation method in Deryng apparatus (Farmakopea Polska V, 2002) as described by Matłok et al. (2020).

Composition of the desorbed compounds was examined using gas chromatograph Varian 450 GC with the mass detector (GC-MS) Varian $240 \mathrm{MS}$ as described by Matłok, et al. (2019).

The compounds were identified based on NIST.08 and Willey data base. The composition of the essential oils isolated from the material was examined using a gas chromatograph Varian 450 GC, as described by Matłok et al. (2020).

\section{Statistical analysis}

A one-way analysis of variance (ANOVA) and multiple pairwise Tukey test was applied in Statistica 13. 


\section{RESULTS AND DISCUSSION}

\section{Pine schots mass reduction}

Ozonation proces of Pinus sylvestris L. young pine shoots resulted in the mass reduction of ozonated plant material (Figure 1). It was observed that the mass reduction of ozonated pine shoots increased with an increasing of the exposure time. The highest reduction was observed for the ozone dose of 10 and $100 \mathrm{ppm}$ and exposition time of 30 minutes. The diference in the observed mass reduction may be atributed to convective drying where the air with ozone surrounds plant material, and thus causes its drying, which in consequence reduces its mass. Mass loss during convection drying was confirmed by several tests (Matłok et al. 2019).

\section{Total phenolic, antioxidant activities and} ascorbic acid content

Ozone is highly reactive form of oxygen which mainly decomposes to reactive oxygen species (ROS) such as superoxide anion radical, hydrogen peroxide and hydroxyl radical in contact with herbs surface. The occurrence of oxidative stress in plant cells is one of main causes of reduced quality of plant products including nutritional value. Such changes can be observed by determination of the total antioxidant potential (Zhou et al., 2014). Therefore, in the presented research the impact of different ozonation conditions on the total antioxidant potential of young pine shoots was determined. The antioxidant potential was determined against synthetic radicals, such as ABTS and DPPH. Moreover, the level of polyphenolic compounds and the vitamin $\mathrm{C}$ content were determined.

As presented on Figure 2, the ozonation process resulted in the change of antioxidant status of young pine shoots. The exposition of plant material to gaseous ozone at the concentration of $10 \mathrm{ppm}$ for up to 15 minutes of the exposition time resulted in an increase in antioxidant activity and in polyphenol and vitamin C content. During the time of storage $24 \mathrm{~h}$ the analysed parameters begun to increase. In the case of a higher ozone dose e.g., 100 ppm, the analysed parameters showed similar tendency but the effect is less spectacular.
Recent reports indicate that antioxidant potential of ozonated plant resources can be corelated with ozonation conditions (Horvitz et al, 2014). A number of research indicate that utilization of mild ozonation conditions results in activation of defensive mechanisms as a consequence of oxidative stress in plant resources. In research by Piechowiak et al. (2019), ozonation of raspberries with an ozone concentration of 8-10 ppm during storage at room temperature for 72 hours resulted in activation of enzymes participating in the neutralization of ROS, e.g., superoxide dismutase and ascorbate peroxidase.

Moreover, it was indicated that an increased level of flavonoids including anthocyanins and the total antioxidant capacity in ozonated raspberries fruits resulted from an increased activity of phenylalanine ammonialyase - an enzyme participating in the biosynthesis of polyphenol compounds. Similar observations were reported in paper by Chen et al. (2019). There, the authors concluded that an increased level of polyphenol compounds in strawberries exposed to ozone at the concentration of $5 \mathrm{ppm}$ for 10 hours resulted from an increased expression of genes encoding phenylalanine ammonialyase.

Roach et al. (2019) concluded that an increased level of activity of the defence mechanisms responsible for reaction against to oxidative stress caused the reduction in accumulation of ROS in ozonated tissue of coriander that was exposed to ozone at the concentration of $0.68 \mathrm{mg} \mathrm{L}^{-1}$ for 10 minutes.

Therefore, an increase of antioxidant activity of young pine shoots after ozonation observed in this study can be attributed to increase of activity of the defence mechanisms responsible for detoxication of ROS, including enzymes responsible for synthesis of antioxidants with a low molecular mass. However, after the maximal antioxidant status was achieved in case of both ozone concentrations, the procedure resulted in gradual decline in levels of compounds that could react with ABTS and DPPH, which was also clearly seen with vitamin C concentration. 


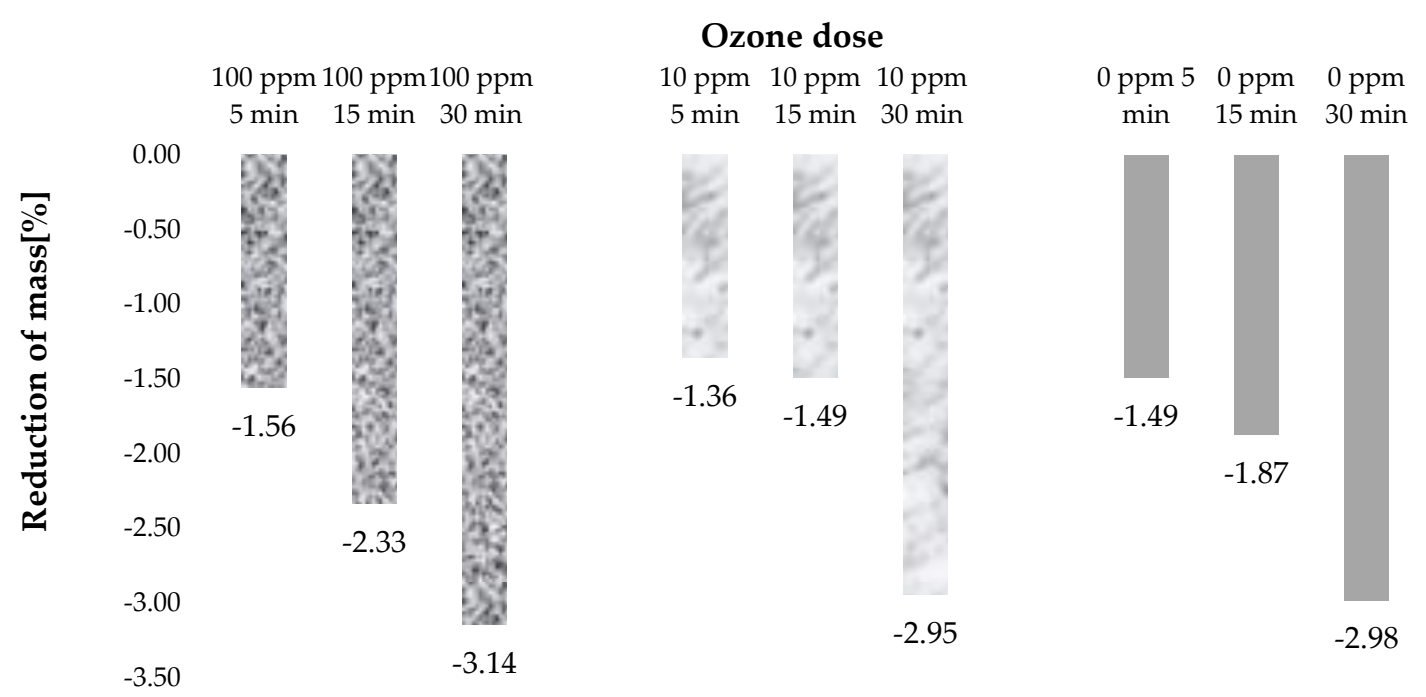

Figure 1. Impact of ozonation process on the mass reduction of Pinus sylvestris L. shoots.
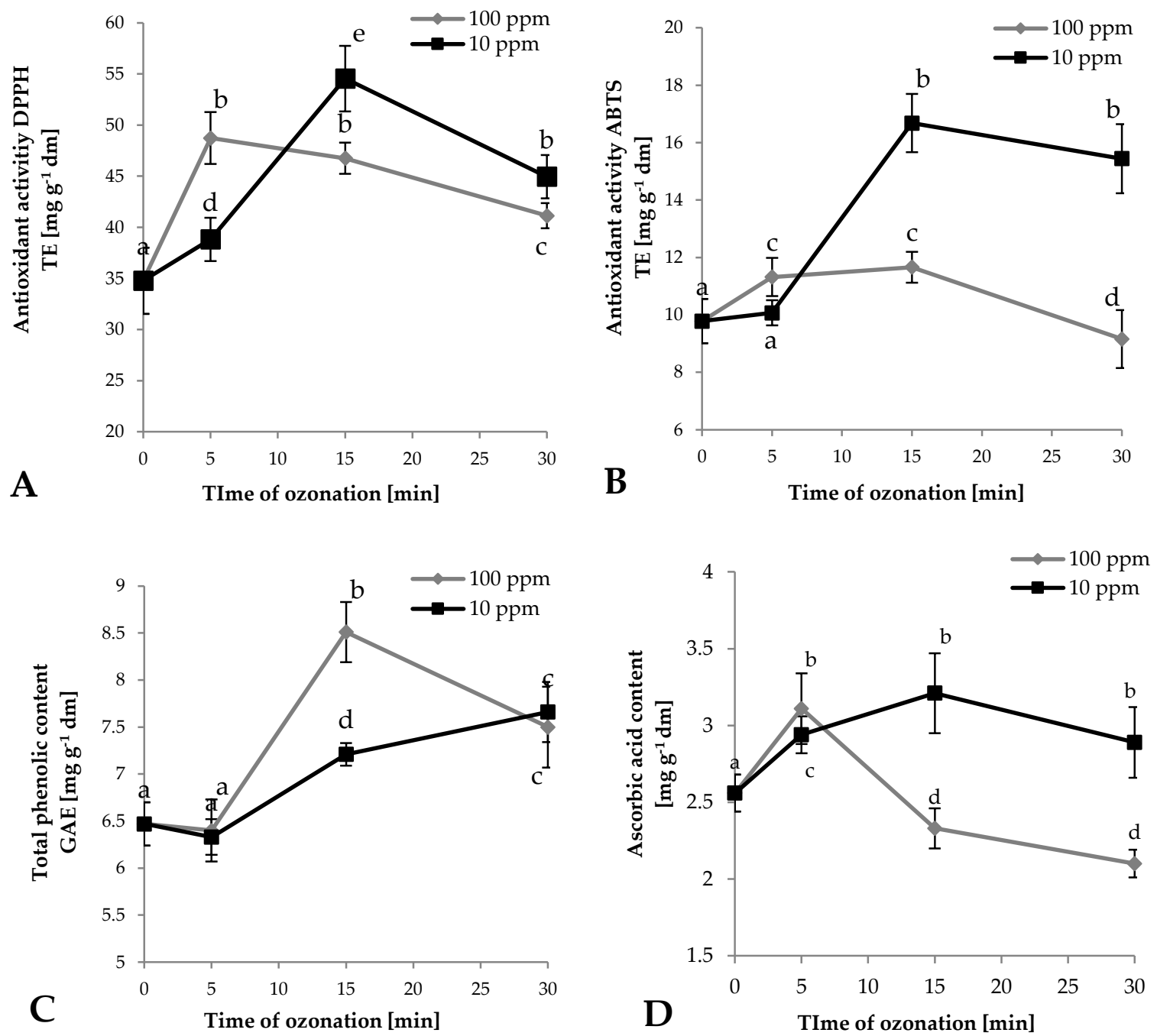

Figure 2. Impact of ozonation process on the antioxidant status of Pinus sylvestris L. On the figure: A - antioxidant activity against DPPH radicals, B- antioxidant activity against ABTS radicals, C- total phenolic content, D - total ascorbic acid content. Mean values with the same lower case are not significantly different to each other according to the T-Tukey test $(\alpha=0.05)$. 


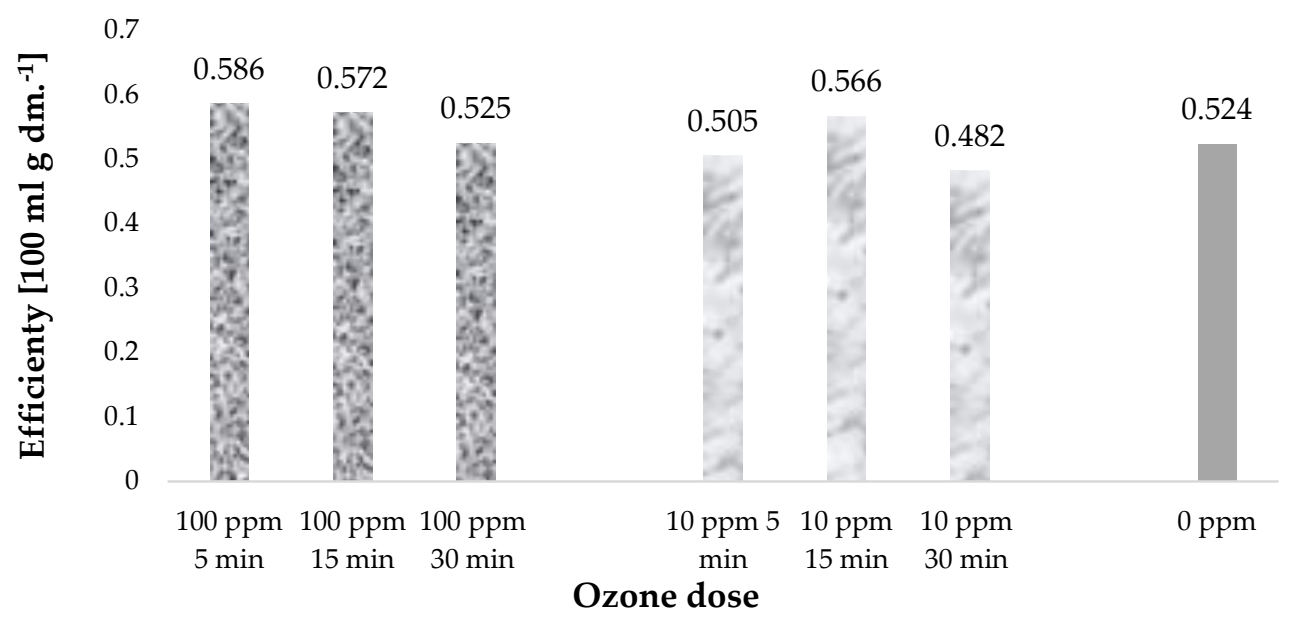

Figure 3. Impact of ozonation process on the efficiency of essential oils with Pinus sylvestris L. shoots

\section{Yield of essential oils}

To analyse relations between the ozone dose (ozone concentration and exposition time) and the yield of essential oils expressed as $\left[\mathrm{ml} 100 \mathrm{~g}^{-1}\right.$ d.m.] that were isolated from ozonated pine shoots, their yield was determined (Figure 3). It was concluded that the application of a various ozone doses caused an increase of the content of some biologically active compounds in Pinus sylvestris L. pine shoots but have only slight impact on yield of isolated essential oils. It was observed that the highest yield of essential oils was $0.586 \mathrm{~mL} 100 \mathrm{~g}^{-1}$ d.m. and was obtained from ozonated pine shoots that were exposed to ozone gas at the concentration of 100 ppm and an exposure time of 30 minutes. This yield was $11.8 \%$ higher than the yield of control sample. An increased yield of essential oils from raw plant materials that were subjected to ozone treatment was also reported by Dąbrowska et al. (2017). Biosynthesis of essential oil compounds, as a secondary metabolites, could be induced with another bioactive compounds synthesis as a result of ozonation process. There it was observed that under the impact of ozone treatment only slight change in the qualitative and quantitative composition of essential oil occurred.

\section{Chemical composition of essential oils}

Essential oils contain metabolites generated during vegetation of plants. The composition of the essential oils that can be obtained from a specific plant depends mainly on plant variety, plant localisation and local environmental conditions.In this manuscript we described the composition of essential oils that were analysed after isolation from Pinus sylvestris L. from same geographic localization. Essential oils are mainly composed of unsaturated hydrocarbon derivatives that are susceptible to strong oxidizing agents, including ozone. This has been shown in a number of works in which direct olefin ozonolysis was carried out. It has been shown that direct effect of ozone during the exposure of pine shoots does not affect the level of volatile substances contained in them. For this purpose, isolation and analysis of essential oils were performed. It was found that the main components of the oil isolated from pine shoots are: 3-carene, Dlimonene and $\alpha$-pinene. Judžentiené et al. (2008) stated that these compounds are typical components of oils isolated from Pinus sylvestris L. pine shoots. Different ozone doses and variable raw material exposure times were used in our studies. The first stage of assessing the impact of the ozonation process on the quality of the pharmaceutical raw material was the initial analysis of the yield of essential oils. At this stage, it showed no significant differences. The next step was qualitative and quantitative analysis using the GC-MS method (see Figure 4, Table 1). Also this analysis showed no significant differences. Oils obtained from the ozonated raw material did not show the presence of oxygen artifacts or potential oxidation products (see Table 1). This confirms that ozone did not directly oxidize cellular components. This observation is highly important in relation to results of other authors who observed changes in the yield and composition of essential oils in ozonated plant material. Brodowska et al., 2014 observed that during the ozonation procedure the essential oils yield increased. The performed analysis of the essential oils composition showed the presence of new originally absent compounds. It was shown that the presence of those compounds originate from oxidation of unsaturated fatty acids and belong to aldehydes (Brodowska 2014b). The use of ozone in the proposed doses did not show phytotoxic properties, but effectively increased its therapeutic quality by activating metabolic pathways of antioxidant biosynthesis, such as polyphenols and vitamin $\mathrm{C}$. 


\section{Chemical composition of HS-SPME}

Analysis of the composition of essential oils showed no effect of ozonation on volatile substances isolated from the plant material. This indicates that ozone was mainly surface-active. Pine shoots as well as other green morphological parts of Pinus sylvestris $\mathrm{L}$. are covered with resinous substances, which are also rich in volatile substances. These parts are exposed to ozone. Due to potentially generated oxygen derivative components of the raw material, its aroma character may change. An effective method of verifying the presence of this type of artifacts is HS-SPME analysis. Before starting the ozonation process, the volatile fraction typical of fresh raw material was determined.
Similarly to the essential oil, the main components of the volatile fraction of this raw material are: 3carene, D-limonene and $\alpha$-pinene, however these compounds are present in different proportions (see Figure 4, Table 1 ). The analysis of the ozonated raw material showed that the signal intensity of individual components as well as the quantitative composition of the volatile fraction is without significant differences. A similar signal height indicates the lack of mineralization of volatile components located on the surface of the ozonated raw material, and the lack of differences in their composition precludes the ozonolysis of unsaturated terpenes.

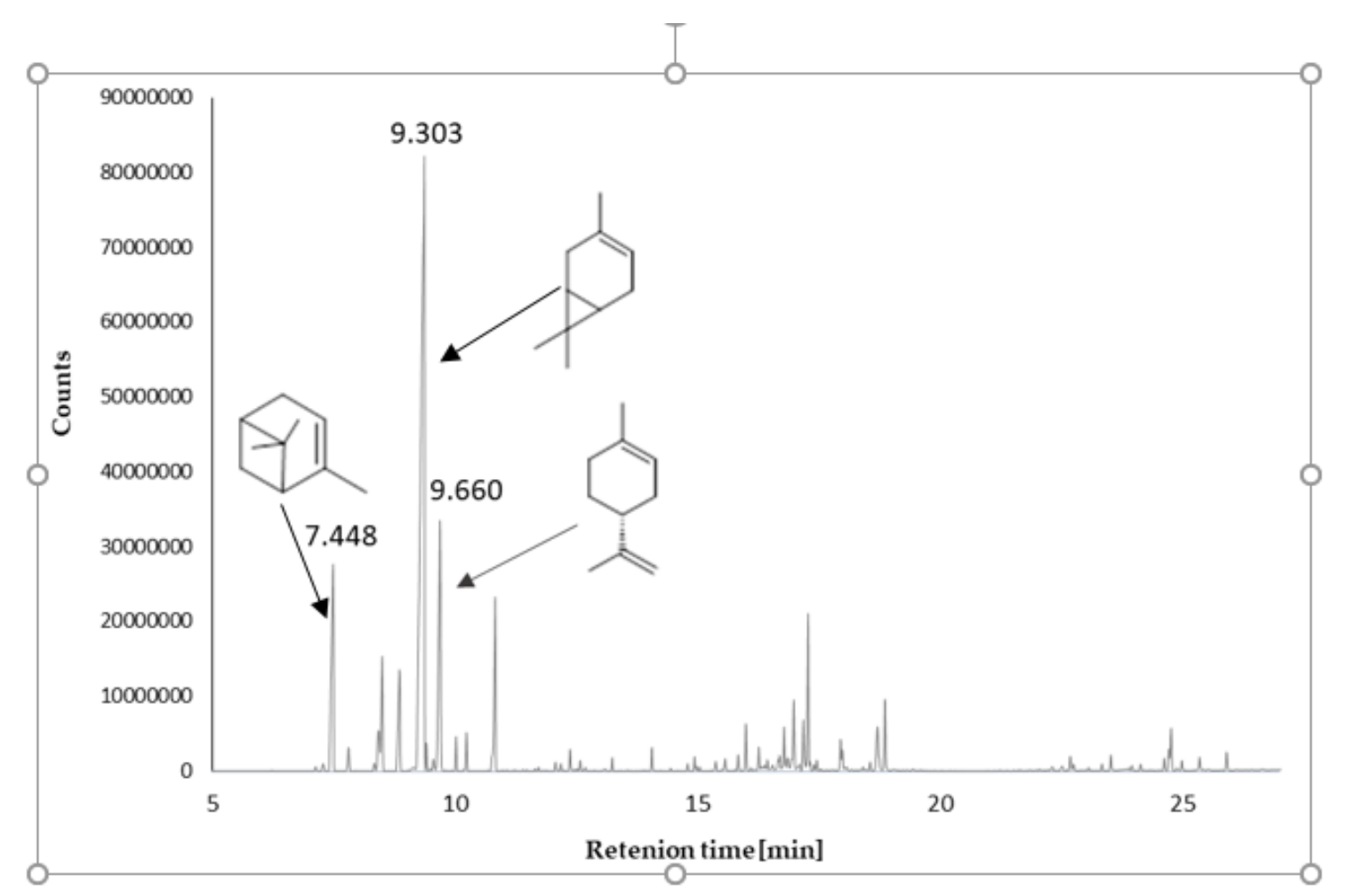

Figure 4. Chromatograms for essential oils isolated from the ozonated (10 ppm, $15 \mathrm{~min}$ ) Pinus sylvestris L.

\section{CONCLUSION}

The ozone treatment induced a significant metabolic response in pine shoots. It was found that the antioxidant potential, polyphenol content and vitamin $\mathrm{C}$ increased after the ozonation procedure. However, this process is limited by ozone dose. The best response to the treatment was observed for the exposure to ozone at the concentration of $10 \mathrm{ppm}$. Optimal ozonation time with the gaseous ozone at the mentioned concentration was 15 minutes. It should be noted that effects of ozonation under proposed conditions were not phytotoxic. This phenomenon was confirmed by the lack of artifacts in the composition of essential oils, as well as the slight impact of ozonation process on their yield. This observation indicates a lack of direct oxidation of cellular components. It has been found that ozonation is an effective elicitor which increase the content of bioactive compounds in the pine shoots. The pine shoots obtained in this way can be a pharmaceutical material with a composition that is unique in nature 


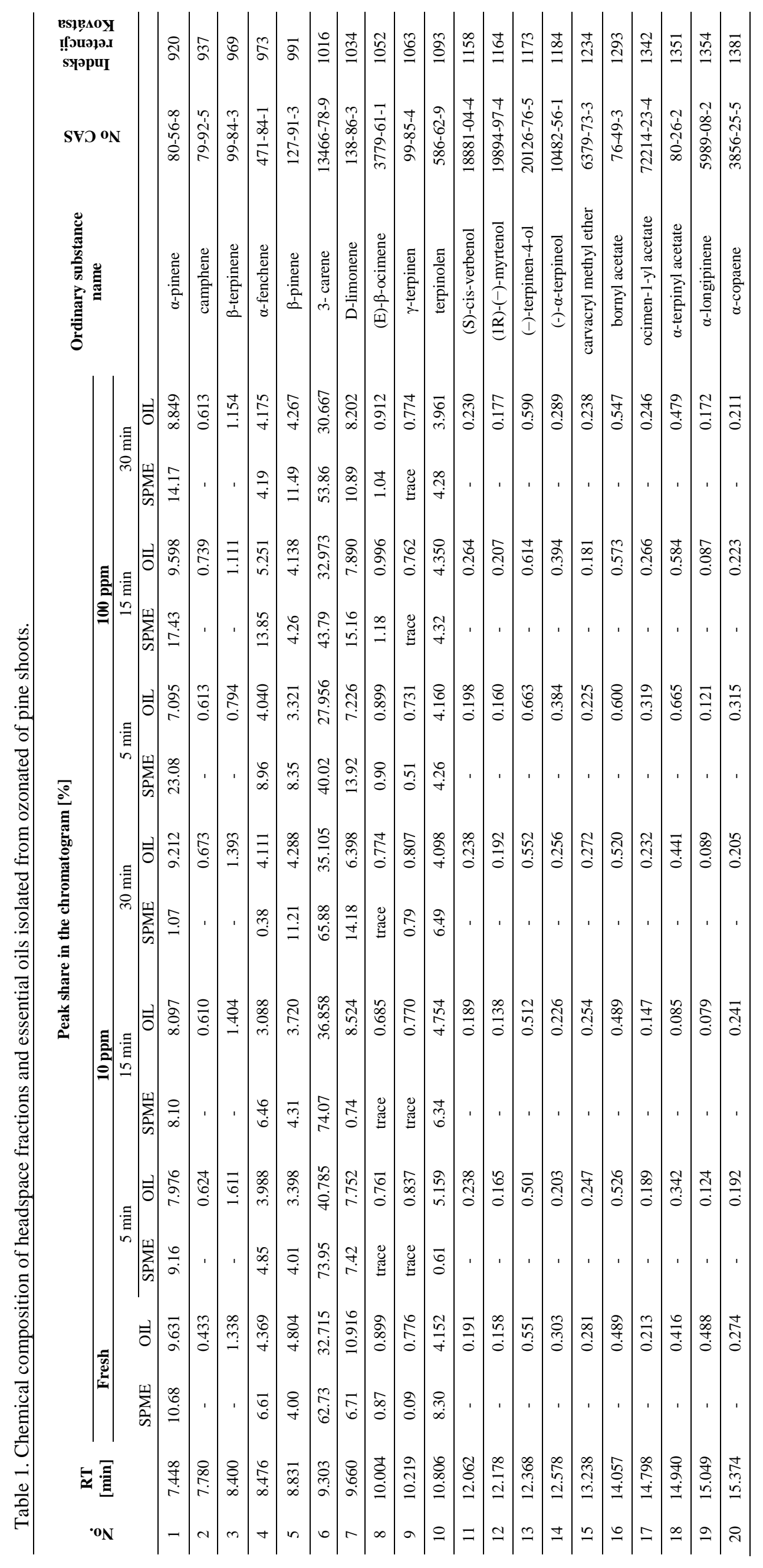




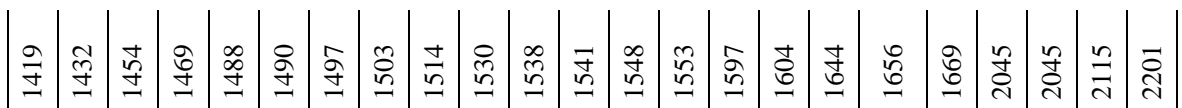

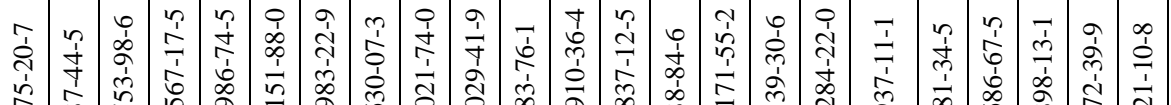

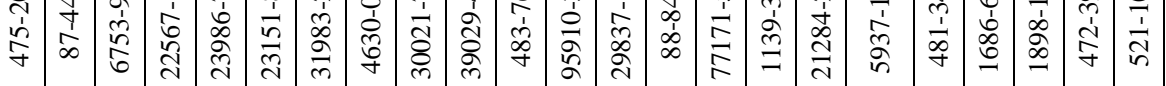

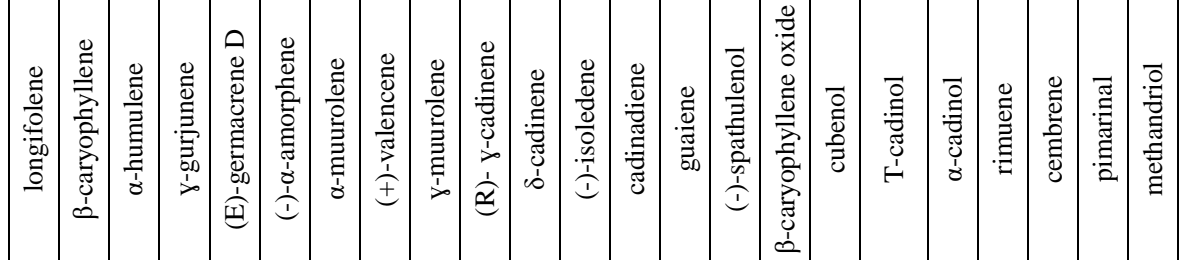

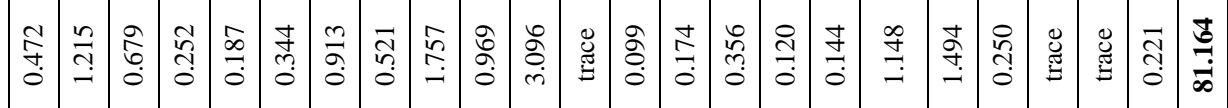

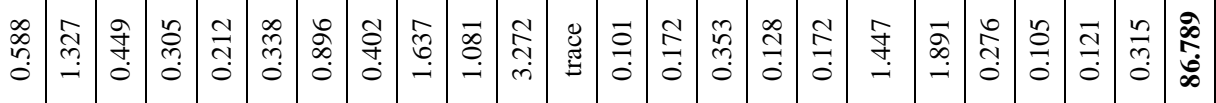

高

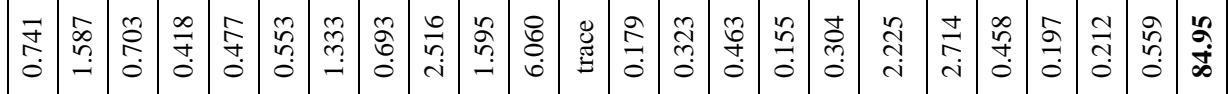

(1)

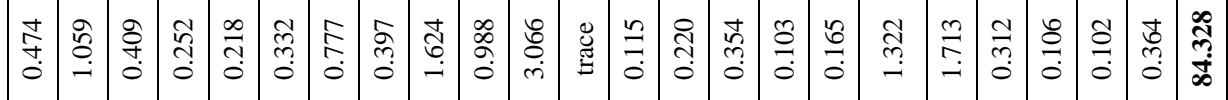

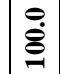

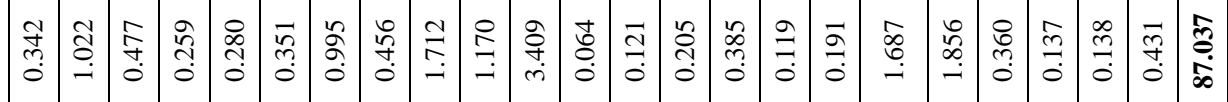

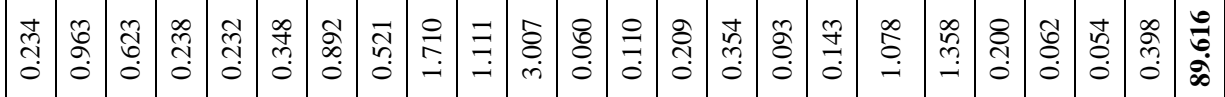

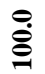

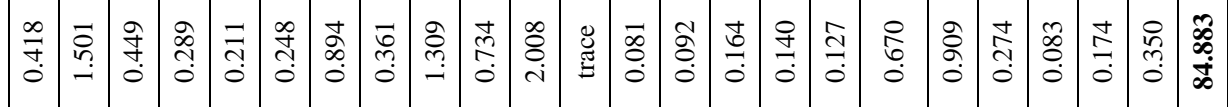

(1)

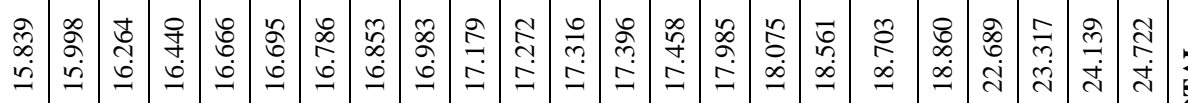

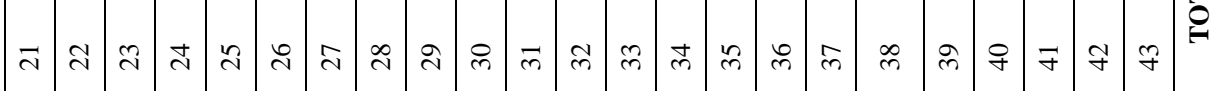




\section{REFERENCES}

1. Ak, T., Gulcin, I. (2008). Antioxidant and radical scavenging properties of curcumin. Chemico-Biolocical Interactions, 174, 27-37. DOI: 10.1016/j.cbi.2008.05.003.

2. Antos, P., Piechowicz, B., Gorzelany, J., Matłok, N., Migut, D., Józefczyk, R., Balawejder, M. (2018). Effect of Ozone on Fruit Quality and Fungicide Residue Degradation in Apples during Cold Storage. Ozone: Science \& Engineering, 39(3), 482-486. https://doi.org/10.1080/01919512.2018.1471389.

3. Bączek, K., Kosokowska, O., Przybył, J. L., Pióro-Jabrucka, E., Kuźma, P., Obiedziński, M., Węglarz, Z. (2017). Intraspecific Variability of Self-sown Scots Pine (Pinus sylvestris L.) Occurring in Eastern Poland in Respect of Essential Oil Content and Composition. Batlic forestry, 23(3), 576-583.

4. Birben, E., Sahiner, U. M., Sackesen, C., Erzurum, S., Kalayci, O. (2012). Oxidative Stress and Antioxidant Defense. World Allergy Organ J., 5(1), 9-19. DOI: 10.1097/WOX.0b013e3182439613.

5. Brodowska, J.A., Śmigielski, K., Nowak, A. (2014a). Comparison of methods of herbs and spices decontamination. CHEMIK, 68(2), 97-102.

6. Brodowska, J.A., Śmigielski, K., Nowak, A., Brodowska, K., Catthoor, R. and Czyżowska, A. (2014b), The Impact of Ozone Treatment on Changes in Biologically Active Substances of Cardamom Seeds. Journal of Food Science, 79: C1649-C1655. doi:10.1111/1750-3841.12591

7. Chen, C., Zhang, H., Dong, C. Ji, H., Zhang, X., Li, L., Ban, Z., Zhang, N., Xue, W. (2019). Effect of ozone treatment on the phenylpropanoid biosynthesis of postharvest strawberries. RSC Advances, 44. https://doi.org/10.1039/C9RA03988K.

8. Daugavietis, M., Polis, O., Korica, A. \& Seleznovs, J. (2002). Priede - augstvçrtîgu, bioloìiski aktîvu dabas vieluavots [Scots pine - a natural raw material for high-qual-ity biologically active substances]. LLU Raksti, 5, 59-67.

9. Dąbrowska, A., Śmigielski, K.B., Kunicka-Styczyńska A. (2017). Ozonowanie surowca roślinnego przed etapem wydzielenia związków biologicznie aktywnych. Advances In Microbiology, 56(2), 25.

10. European Spice Association, (2013). Quality Minima Document, [Online] Available: https://www.esaspices.org/index-esa.html/publications-esa [4 March 2017].

11. Farmakopea Polska, VI. (2002). Wydawnictwo Urząd Rejestracji Produktów Leczniczych, Wyrobów Medycznych i Produktów Biobójczych, Polska, (in Polish).

12. Gorzelany, J., Migut, D., Matłok, N., Antos, P., Kuźniar, P. \& Balawejder, M. (2016). Impact of PreOzonation on Mechanical Properties of Selected Genotypes of Cucumber Fruits During the Souring Process. Ozone Science and Engineering, 39(3). https://doi.org/10.1080/01919512.2016.1273756.

13. Horvitz, S. \& Cantalejo, M.J. (2014). Application of ozone for the postharvest treatment of fruits and vegetables. Critical Reviews in Food Science and Nutrition, 54(3), 312-39. https://doi.org/10.1080/10408398.2011.584353.

14. Judžentienè, A., Šližytė, J., Stiklienè, A. \& Kupčinskienė, E. (2006). Characteristics of essential oil composition in the needles of young Scots pine (Pinus sylvestris L.) stands growing along an aerial ammonia gradient. CHEMIJA, 17(4), 67-73.

15. Judžentienè, A. \& Kupčinskienè, E. (2008). Chemical Composition on Essential Oils from Needles of Pinus sylvestris L. Grown in Northern Lithuania. Journal of Essential Oil Research, 20(1), 26-29. https://doi.org/10.1080/10412905.2008.9699413.

16. Kędzia, A., Ziółkowska-Klinkosz, M., Kędzia, A.W., Wo-jtaszek-Słomińska, A., Kusiak,A. \& Kochañska, B. (2012). Antifungal activity of pine oil (Oleum Pini sylvestris). Postępy Fitoterapii, 4, 211 215.

17. Kohlmûnzer, S. Farmakognozja (Pharmacognosy) (2010). Wydawnictwo Lekarskie PZWL, Warszawa, 592 pp. (inPolish).

18. Matłok, N., Gorzelany, J., Stępień, A.E., Figiel, A., Balawejder, M. (2019). Effect of Fertilization in Selected Phytometric Features and Contents of Bioactive Compounds in Dry Matter of Two Varieties of Basil (Ocimum basilicum L.). Sustainability, 11(23), 6590. https://doi.org/10.3390/su11236590.

19. Matłok, N., Gorzelany, J., Piechowiak, T., Balawejder, M. (2020). Influence of Drying Temperature on the Content of Bioactive Compounds in Scots Pine (Pinus sylvestris L.) Shoots as Well as Yield and Composition of Essential Oils. Acta Universitatis Cibiniensis. Series E: Food Technology, 24(1), 1-14.

20. Mason, W. L., Alía, R. (2000). Current and future status of Scots Pine (Pinus sylvestris L.) forests in Europe. Investigación agraria. Sistemas y recursos forestales, 9(1), 317-336.

21. Motiejûnaitë, O. and Peèiulytë, D. (2004). Fungicidal properties of Pinus sylvestris L. for improvement of air quality. Medicina, 40(8), 787-794. 
22. Nunesa, F. M.N., Velosoab M.C.C., de P. Pereiraa, P.A., de Andradea J.B. (2005). Gas-phase ozonolysis of the monoterpenoids (S)-(+)-carvone, $(\mathrm{R})-(-)$-carvone, $(-)$-carveol, geraniol and citral. Atmospheric Environment, 39(40), 7715-7730. https://doi.org/10.1016/j.atmosenv.2005.04.009.

23. Piechowiak, T., Antos, P., Kosowski, P., Skrobacz, K., Józefczyk, R., Balawejder, M. (2019). Impact of ozonation proces on the microbiological contamination and antioxidant status of raspberries (Rubus idaeus L.) during storage at room temperature. Agricultural and Food Science, 28(1), 35-44.

24. Piechowiak, T., Balawejder, M. (2019). Impact of ozonation proces on the level of selected oxidative stress markers in raspberries stored at room temperature. Food Chemistry, 298(15),125093. DOI: 10.1016/j.foodchem.2019.125093.

25. Rice, R., G., Graham D., M., Lowe, M., T. (2013). Recent ozone applications in food processing sanitation, Food Safety Magazine, [Online] Available: http://www.foodsafetymagazine.com/magazinearchive1/octobernovember-2002/recent-ozone-applications-in-food-processing-and-sanitation/ [4 March 2017].

26. Roach, T., Krieger-Liszkay, A. (2019). Photosynthetic Regulatory Mechanisms for Efficiency and Prevention of Photo-Oxidative Stress. Annual Plant Reviews, 2(1), 1-34. https://doi.org/10.1002/9781119312994.apr0666.

27. Strzelecka, H., Kowalski, J. (2002). Encyklopedia zielarstwa i ziołolecznictwa [Encyclopedia of herbs and herbal medicine]. Wydawnictwo Naukowe PWN, 556 (in Polish).

28. Tanko, H., Carrier, D. J., Duan, L., Clausen, E. (2005). Pre-and post-harvest processing of medicinal plants. Plant Genetic Resources, Cambridge University Press, 3(2), 304-313. DOI: https://doi.org/10.1079/PGR200569

29. Thoss, V., OReilly-Wapstra, J. and Iason, G.R. (2007). Assessment and implications of intraspecific and pheno-logical variability in monoterpene of Scots pine (Pinus sylvestris) foliage. Journal of Chemical Ecology, 33, 477-491. DOI: 10.1007/s10886-006-9244-3.

30. Torlak, E., Sert, D., Ulca, P. (2013). Efficacy of gaseous ozone against Salmonellaand microbial population on dried oregano. International Journal of Food Microbiology, 165, 276-280. DOI: 10.1016/j.ijfoodmicro.2013.05.030.

31. Tümen, I., Hafizoglu, H., Kilic, A., Dönmez, I.E., Sivri-kaya, H. and Reunanen, M. (2010). Yields and Constit-uents of Essential Oil from Cones of Pinaceae spp. Natively Grown in Turkey. Molecules, 15(8), 5797-5806. DOI: 10.3390/molecules15085797.

32. Ulukanli, Z., Karabörklü, S., Bozok, F., Ates, B., Erdogan, S., Cenet, M., Karaaslan, M. G. (2014). Chemical composition, antimicrobial, insecticidal, phytotoxic and antioxidant activities of Mediterranean Pinus brutia and Pinus pinea resin essential oils. Chinese Journal of Natural Medicines, 12(12), 09010910. DOI: 10.1016/S1875-5364(14)60133-3.

33. Weschler, C. J., Shields, H. C. (1999). Indoor ozone/terpene reactions as a source of indoor particles. Atmospheric Environment, 33(15), 2301-2312.

34. Zhou, Q., Zhang, C., Cheng, S., Wei, B., Liu, Ji, S., (2014). Changes in energy metabolism accompanying pitting in blueberries stored at low temperature. Food Chemistry, 164, 493-501. DOI: 10.1016/j.foodchem.2014.05.063. 